ARCHAEOLOGY IN GREECE 2016-2017

\title{
Recent research at the Sanctuary of Artemis Amarysia in Amarynthos (Euboea)
}

\author{
Sylvian Fachard | ASCSA | sfachard@ascsa.edu.gr
}

Denis Knoepfler | Collège de France | Denis.Knoepfler@unine.ch

Karl Reber | University of Lausanne/ESAG | Karl.Reber@unil.ch

Amalia Karapaschalidou | Ephorate of Antiquities of Euboea| amaliakarapasxalidou@gmail.com

Tobias Krapf | ESAG/Swiss National Science Foundation | Tobias.Krapf@unil.ch

Thierry Theurillat | ESAG | Thierry.Theurillat@unil.ch

Pari Kalamara | Ephorate of Antiquities of Euboea|pkalamara@culture.gr

\section{Introduction}

The Sanctuary of Artemis Amarysia in Amarynthos was the most renowned shrine of the Eretrian polis, and its annual festival, the Artemisia, drew large crowds from Euboea and beyond. Yet, despite its regional fame and prominence, its remains have eluded archaeological identification. As a result, the location of the Artemision has been a vexed question in Euboean studies for over a century. Between 2003 and 2007, however, a new impetus was given to its localization. In collaboration with the Ephorate of Antiquities of Euboea, the Swiss School of Archaeology in Greece (ESAG) carried out a large-scale geophysical survey in the area of Amarynthos, some $11 \mathrm{~km}$ east of Eretria, at the foot of a hill locally known as Paleoekklisies (or Paleochora). The ensuing trial trenches were followed by systematic excavation that eventually led to the discovery of substantial buildings. We suggest that these buildings are part of a monumental complex that should be identified as the Sanctuary of Artemis Amarysia (see afterword).

After stressing the importance of the Artemision of Amarynthos and recapitulating the history of the project, this article summarizes a decade of archaeological research in Amarynthos and presents the latest evidence for the location of the shrine.

\section{The role and importance of the Artemision}

The historical importance of the Artemision of Amarynthos mainly derives from the chapter that Strabo dedicated to the island of Euboea in the tenth book of his Geography (10.1.1-13). The Hellenistic sources consulted by Strabo indicated that this sanctuary, situated in the vicinity of Eretria (see below for the indication of distance), hosted important public documents. Among them was a law regulating the annual procession from Eretria to Amarynthos. This ceremony took the form of a military parade composed of 3,000 heavily armed warriors (hoplitai), 600 cavalrymen (hippeis) and 60 war chariots (harmata). These contingents may be related to an underlying, sophisticated political structure, perhaps linked in some way to the distribution of the Eretrian civic body into six tribes (phylai) from ca. $500 \mathrm{BC}$ (roughly at the same time that Athens instituted its ten tribes). Possibly, each tribe provided 500 infantrymen, 100 cavalrymen and 10 war chariots (Knoepfler 2010). A second document recorded by Strabo is the military agreement between the rival cities of Chalkis and Eretria, supposedly banning the use of missiles (Die Staatsverträge des Altertums 102) - a treaty that has most often been associated with the semi-mythical Lelantine War (but its authenticity may be questioned: see, in particular, Wheeler 1987; Krentz 2002).

The function of epiphanestatos topos - a privileged place for displaying the deeds of the Eretrieôn polis - has been confirmed by several epigraphic discoveries made since the $19^{\text {th }}$ century. A treaty between Eretria and Histiaia (in northern Euboea) dated to 400 BC discloses that the Eretrian copy of the decree shall be displayed in Amarynthos (IG XII 9, 188; Die Staatsverträge des Altertums 205). Second-century 
$\mathrm{BC}$ honorific decrees attest that benefactors of the polis were memorialized by the dedication of two bronze statues: one erected in the city gymnasium and the other in the Artemision. During the same period, an effigy of Artemis Amarysia appeared on the obverse of several Eretrian emissions - tetradrachms and octobols, on the reverse of which is a bovid adorned and offered as a sacrifice to Artemis.

The political role played by this deity is attested in other texts and documents. Among the most significant is a stele, displayed in the sanctuary ( $\dot{\varepsilon} \vee \tau \tilde{\omega} 1$ i $\varepsilon \rho \tilde{\omega} \iota \tau \tilde{\eta} \varsigma$ A $\rho \tau \dot{\varepsilon} \mu 1 \delta \circ \varsigma)$, which established and regulated a new competition intended to enhance the splendour of the Artemisia festival (IG XII 9, 189; Rhodes and Osborne 2003: n. 73, with English translation). The deity is concurrently designated as Metaxy ('the One of the Middle') and Phylake ('the Watch and Guard'), an appellation that was elucidated only recently (Knoepfler 2008). It refers to the period of civil strife (stasis) that, for several years, tore apart the polis of Eretria and threatened its existence. Artemis, however, remained above the fray and ensured the salvation of its people. Consequently, once liberated from tyranny and having recovered their former prosperity, the Eretrians expressed their appreciation to Artemis by establishing a musical competition, thus celebrating her guardianship through poetic and instrumental events (including prizes of money likely to attract numerous competitors).

A fourth-century BC inscription, the Eretrian Law against Tyranny and Oligarchy (SEG 51.1105), brings to light an otherwise unattested feature of the Artemisia and confirms the sanctuary's political importance. This law stipulates that opponents of the democratic regime will be under a solemn curse, which will be pronounced annually by all priests and priestesses during the two major festivals: the Dionysia celebrated in the city and the Artemisia in Amarynthos. The text also stipulates that the tithe on confiscated property once belonging to citizens sentenced to death or exile will be directed to Artemis Amarysia. This clause establishes Artemis' treasury as Eretria's most important sacred fund.

Ranked first in the Eretrian pantheon, alongside her brother Apollo Daphnephoros (patron deity of the main urban shrine), Artemis Amarysia was also venerated beyond Eretrian borders. In Attica, an Amarysion is attested in the deme of Athmonon, north of Athens (the modern name, Maroussi, derives from this yet unlocated shrine). An official document from Athens demonstrates that before the Peloponnesian War the cult of Artemis Amarysia had expanded from Athmonon (Athmonothen) to Kydathenaion, an urban deme located at the foot of the Acropolis $\left(I G \mathrm{I}^{3} 426,65-69\right)$. Pausanias understood that the origin of this festival was to be found 'in Amarynthos where the Euboeans still worship Artemis Amarysia' (1.32.5). If Pausanias mentions the Euboeans and not specifically the Eretrians, it is because he was probably aware of the Paneuboic dimension of the Artemisia. Indeed, Livy (35.38.3, drawing on a passage in Polybios) asserts that people from Chalkis and Karystos joined the Eretrians in Amarynthos for the annual celebration of the goddess (sacrum anniversarium Amarynthidis Dianae). Incidentally, an inscription from Karystos has confirmed this testimony (Knoepfler 1972).

Therefore, in all likelihood, the Artemision was Euboea's most renowned shrine. Consequently, it is not unreasonable to believe that it enjoyed the status of a koinon hieron - a sanctuary common to the whole Euboean ethnos - at the beginning of the fourth century BC at the latest, when the first attempts towards a Euboean federal union were made (Knoepfler 2015). The cult itself must, however, be much older, extending back to the Geometric, and perhaps even to the Mycenaean period, when the name Amarynthos (a-ma-ru-to) appears on the Linear B tablet TH Of 25 and on one of the inscribed sealings

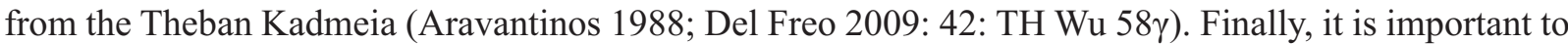
stress that Artemis was celebrated in Amarynthos along with other deities, such as the Eretrian hero Narkittos/Narcissus, who was Amarynthos' son according to an old local tradition (Knoepfler 2010).

\section{Searching for the Artemision}

Until the $19^{\text {th }}$ century, very few European travellers and Greek archaeologists (Ackermann and Knoepfler 2009) doubted that the Sanctuary of Artemis Amarysia was near Eretria. Strabo's testimony discloses the position of the small town (kome) of Amarynthos: 7 stadia (ca. 1,250m) from the city walls (teichos). Early scholars thus felt confident that locating the site would not be challenging. This confidence, however, was undermined in 1900, when Rufus B. Richardson (1895: 336-37), affiliated with the American School 
of Classical Studies, failed to locate the sanctuary. Conversely, several accidental discoveries made in the region of Kato Vathia suggested that the Artemision might be located further to the east, in the area of the Paleoekklisies hill. Konstantinos Kourouniotis (1900) gathered epigraphic evidence which favoured this location. Likewise, in 1934 Erich Ziebarth discovered a copy of an inscription known from the gymnasium in Eretria near Paleoekklisies: the final clause states that the stele should be displayed in duplicate, one copy in the city gymnasium, the other in the Sanctuary of Artemis in Amarynthos (IG XII 9, 236 and Supplement 555). This discovery should have, once and for all, directed investigations to the area of the Paleoekklisies hill.

However, the debate about the position of Amarynthos continued. Some scholars hesitated to discard Strabo's precise testimony (even though he never visited the island). Many archaeologists, like John Boardman (1957), followed the traditional localization and focused on remains located in the suburban area of Eretria (at Magoula; Fig. 131). The reopening of systematic excavations at Eretria in 1964 by the future ESAG (the year the British School at Athens started the Lefkandi excavations) did not move the question forward because the primary mission was to focus on the urban remains. Amongst Swiss scholars, Olivier Reverdin and François Lasserre remained faithful to the Strabonian alleged distance by proposing a localization near the chapel of Agia Paraskevi, only 1,200m distant from the city wall (Lasserre 1971), while others, like Karl Schefold, were more receptive to the Paleoekklisies hypothesis (Schefold and Auberson 1972). For his part, Petros Themelis suggested a subtle compromise by distinguishing two sanctuaries that Strabo might have accidentally confused: an Amarysion near Eretria and a second one in Amarynthos (Themelis 1969). This attempt, however, proves to be linguistically disputable. Indeed, the adjective Amarusia - the only authentic form of Artemis' epiclesis - is a direct derivative of Amarunthios (by a very old assibilation phenomenon).

In the early 1970s, Denis Knoepfler carried out a systematic study of the available evidence (Knoepfler 1972). He reached the conclusion that the distance given by Strabo is incorrect; it is contradicted by other accounts, in particular by Ptolemy's map (second century AD), which implies that Amarynthos was a coastal site situated $15 \mathrm{~km}$ southeast of Eretria. But how can such a mistake be accounted for? In all probability, Strabo should not be blamed for this error. It seems likely that at some point in the transmission of the text, the written numbers were replaced by numbers spelled in alphabetical notation. In the latter system, the number seven ( $\dot{\varepsilon} \pi \tau \alpha$ ) is transcribed by the letter $\zeta(z e t a)$, whose mark is almost identical to the letter $\xi(x i)$, which equals $60(\dot{\varepsilon} \xi \dot{\eta} \kappa o v \tau \alpha)$. A Byzantine copyist could have easily mistaken a $\zeta$ for a $\xi$. Therefore, it can be reasonably assumed that the original text of the Geography reported the distance as 60 stadia (and not seven) between Eretria and Amarynthos. This distance (approximately 10.8km) perfectly fits the length of a direct path between Eretria's East Gate and the western foot of the Paleoekklisies hill (Fig. 131). Therefore, the distance of 60 stadia - precisely measured, as was customary in ancient Greece - was the length of the Sacred Road (hiera hodos) leading from Eretria to its main extramural shrine. This hypothesis, first presented at the Académie des Inscriptions et Belles-Lettres in Paris 30 years ago (Knoepfler 1988), has been well received. However, it still needed to be validated by the discovery of remains that could be securely identified with the sanctuary. This required a further 20 years of investigations.

Although the general location of the sanctuary could now be more confidently reconstructed, no architectural remains were visible, even though much modern building had taken place since the 1960s in

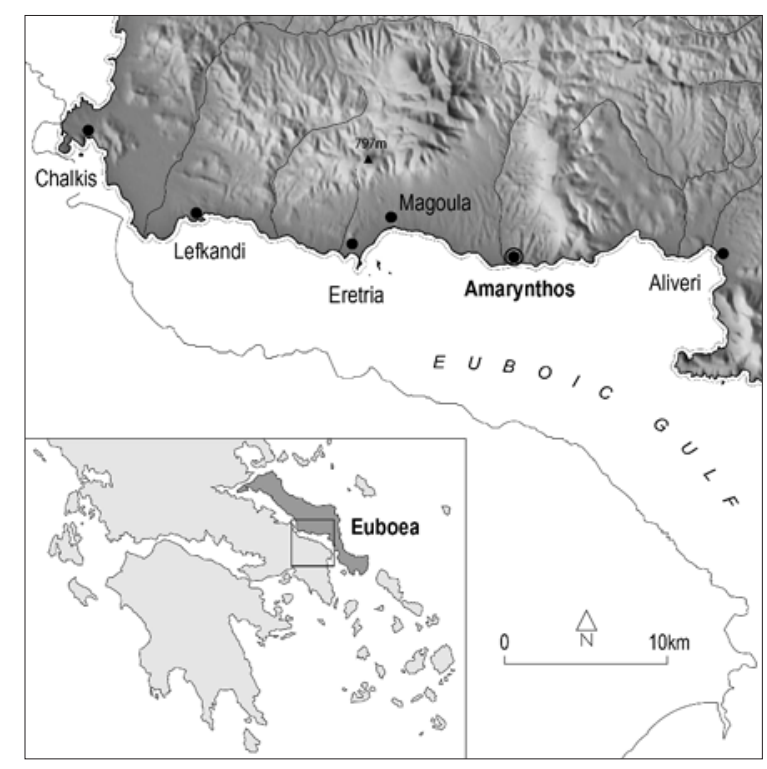

131. Map of central Euboea. (C) ESAG. 
this area. Moreover, a discovery made in 1987 complicated the orientation of field investigations. A pit containing rich ceramic and coroplastic material of various dates was discovered by the Greek Archaeological Service at a place known as Agia Kyriaki, some 800m northwest of Paleoekklisies (SapounaSakellaraki 1989; 1992). This discovery redirected research away from the hill. In our opinion, however, this bothros was most probably a cache used by illegal diggers, and, since the provenance of the material could not be secured, it provided no valid topographical information indicative of the localization of the sanctuary. Moreover, no structural remains were discovered in the ensuing excavations. Nevertheless, at this point, it seemed that the sanctuary could have been buried under the thick alluvial deposits of the Sarandapotamos delta, in an area of several square kilometres. The site of the Artemision looked as though it might remain a mystery for some time to come.

Between 2003 and 2004, however, new investigations brought clarity to the question of the Artemision's location. In collaboration with the Ephorate of Antiquities of Euboea, ESAG carried out a large-scale geophysical survey in the area of the Paleoekklisies hill (Fachard 2004; 2005). The survey was followed by trial trenches in 2006 (Theurillat and Fachard 2007). In 2007, the foundations of a major building buried $2.10 \mathrm{~m}$ below the surface were discovered at the western foot of the hill (Fachard and Theurillat 2008). This discovery proved to be a turning point in the search (Knoepfler 2008). Over the course of the following decade, strategically located private plots were acquired, and the Greek-Swiss team extended the area of excavation (Knoepfler 2010; Reber et al. 2013; Knoepfler et al. 2014; 2015; 2016; 2017). Several ancient buildings, including a large stoa, were unearthed, suggesting the existence of a monumental complex in this sector - in all probability, the Sanctuary of Artemis Amarysia (Figs 132-34).

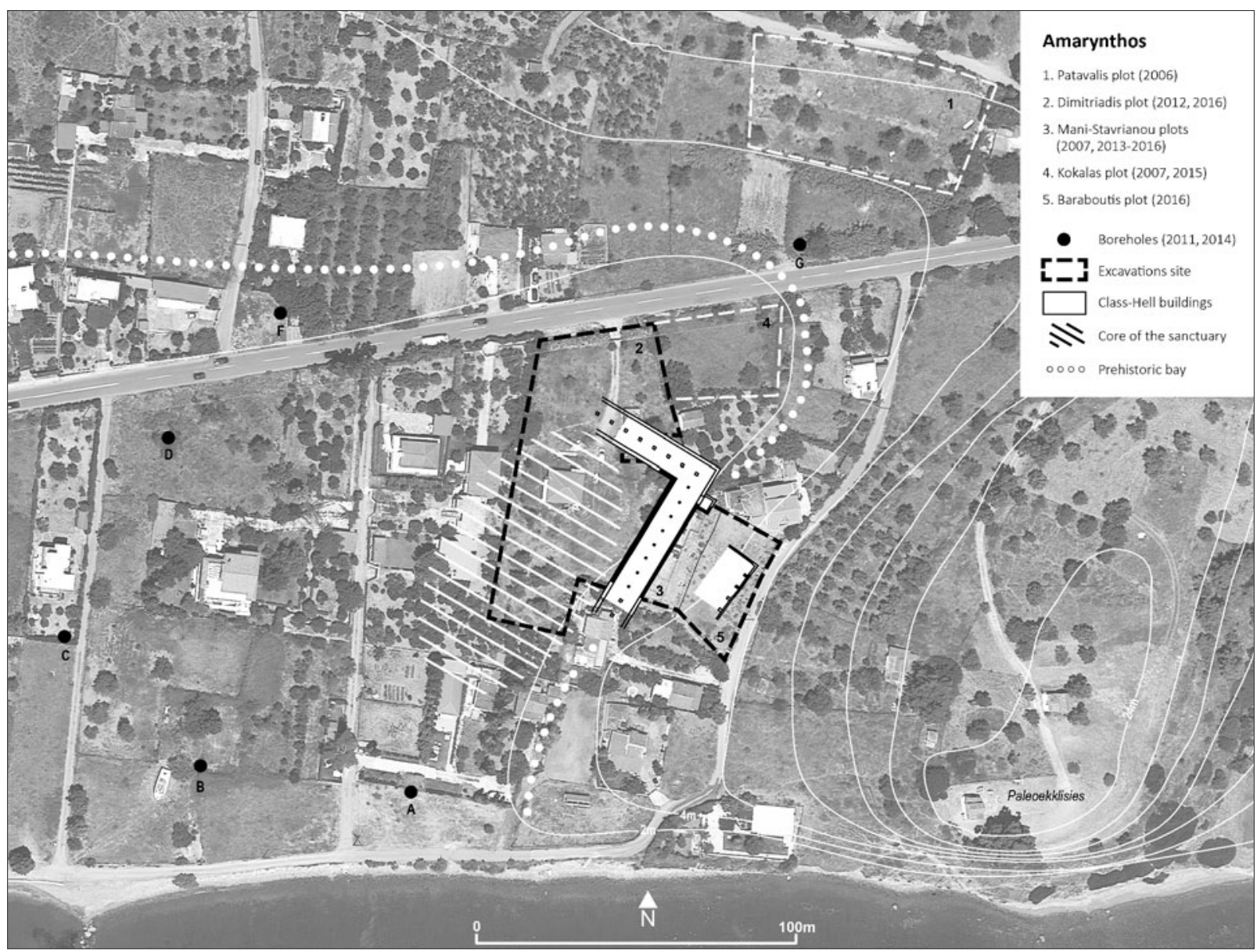

132. The Paleoekklisies area. (C) ESAG. 


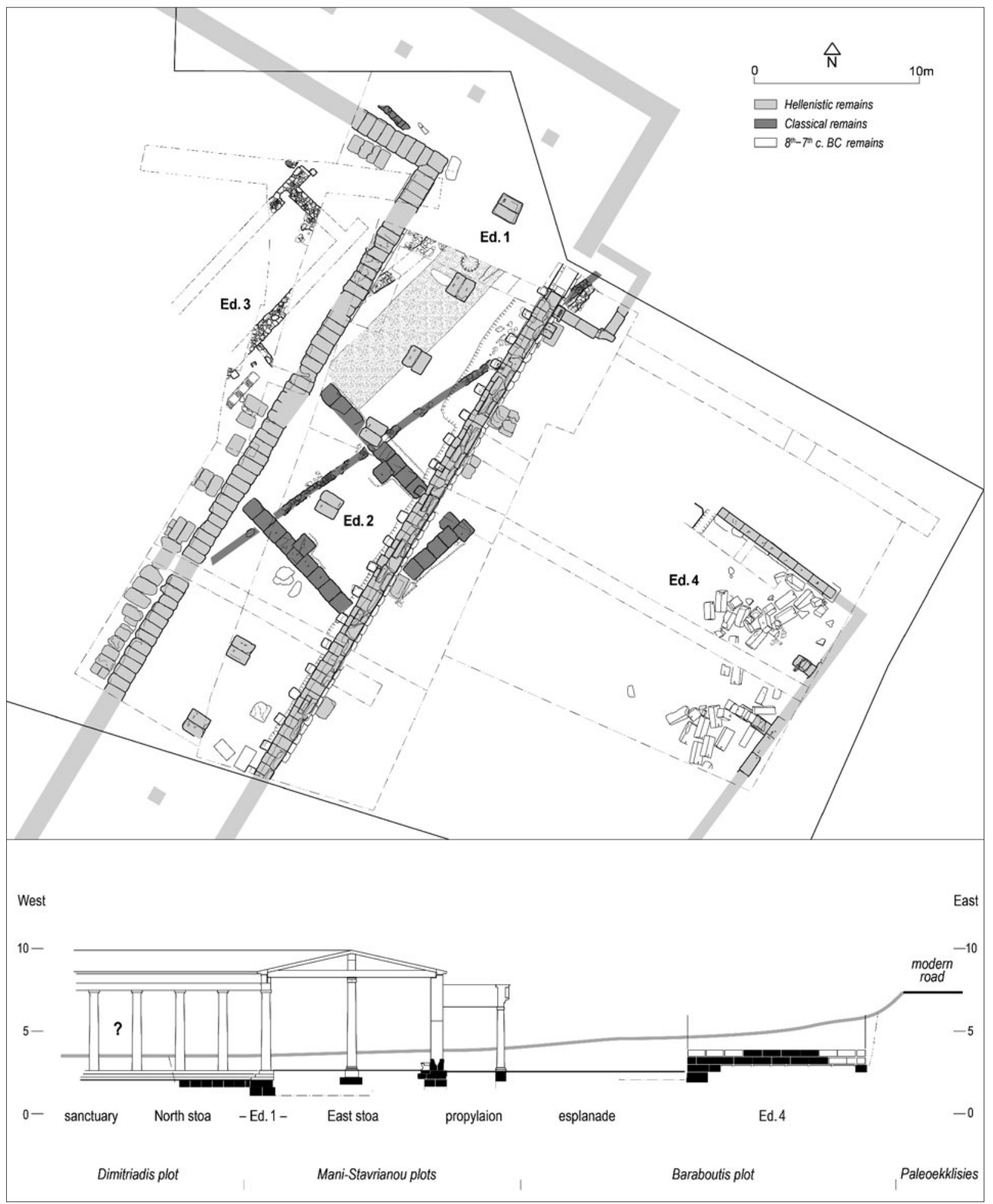

133. Paleoekklisies: plan of the excavations and profile of the reconstructed East Stoa and Building 4. (C) ESAG. 


\section{The palaeoenvironment}

The Paleoekklisies hill is a coastal eminence that occupies the eastern edge of the Sarandapotamos river drainage basin, probably called the Erasinos in Antiquity. The promontory, which consists of Upper Miocene fluvio-lacustrine deposits affected by heavy coastal erosion, is characterized by rugged cliffs which face the sea to the south and steep slopes on its eastern, northern and western sides. The coastal area of the lower basin consists of Holocene alluvial deposits, clayey-sandy materials with cobbles. The geoarchaeological study of the area, which included coring, resulted in a paleoenvironmental reconstruction of the landscape (Ghilardi et al. 2012). From the Early Holocene to $c a .2,600-2,400 \mathrm{BC}$, the area was characterized by a fully marine environment. This then developed into a brackish/closed lagoon from the Early Helladic to the Late Geometric period ( $c a .750$ $\mathrm{BC}$ ), mostly due to the deltaic progradation of the Sarandapotamos river. From the end of the eighth century $\mathrm{BC}$ onwards, the lagoon was progressively replaced by swamps. Therefore, the site associated with the sanctuary was built between a coastal marsh environment to the west and Paleoekklisies hill to the

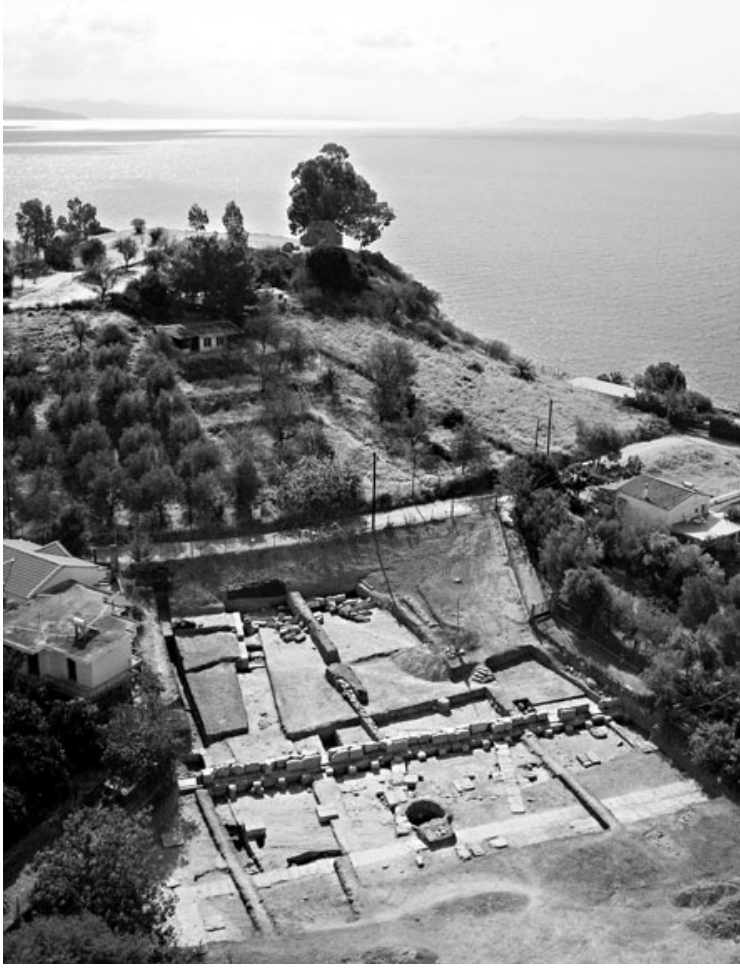

134. Paleoekklisies: the excavation at the foot of the hill.

(C) ESAG. east, at a maximum distance from the sea of some 80-100m (Fig. 132). The results of the geoarchaeological study show that however large the sanctuary was, its southern and southwestern limits can not extend beyond the four cores that delimit the coastal swamps that existed from the Archaic to the Late Hellenistic period (Ghilardi et al. 2012).

\section{The Bronze Age}

Prehistoric occupation at the site was already acknowledged by Vronwy Hankey in 1939 (Sackett et al. 1966: 65). In 1966 the British survey team published the Bronze Age pottery collected from Paleoekklisies hill (Sackett et al. 1966: 64-66). The topographical setting of this coastal hill is typical of the region's Bronze Age sites and shares many parallels with Drosia, Dramesi and Lefkandi. The latter, in particular, bears close similarities to Paleoekklisies, with its two anchorages (now silted up) behind the tell. Architectural features belonging to all Bronze Age phases have been excavated on top of the hill by Liana Parlama (1979) and Efi Sapouna-Sakellaraki (1989). Middle Bronze Age layers were later found by the Greek-Swiss team some $150 \mathrm{~m}$ northwest of the hill in trial trenches positioned on a plot where anomalies were detected during the geophysical survey (ID529). This attests to a settlement that, at least during some periods, extended beyond the confines of the hill onto the plain, on the northern side of the aforementioned lagoon. In 2009, Early Bronze Age features were excavated east of the hill by the Ephorate (Kalamara 2015: 157). No Bronze Age structures, however, were discovered in the area excavated since 2012, as this sector must have been submerged, forming a natural harbour. Substantial slope deposits covering the area, especially Building 4, contain thousands of Prehistoric sherds (Fig. 135) and obsidian tools.

The date of the earliest habitation at the site remains unclear. Two sherds have been 'tentatively ... assigned to the Late Neolithic period' (Sackett et al. 1966: 64), but this has not been confirmed by the latest finds. In the Early Bronze Age, Paleoekklisies hill was one of many sites located along the coast of the Euboean Gulf. The hill enjoys unhindered visibility in the direction of Eretria and Magoula. Amarynthos seems to have expanded over the course of the Middle Bronze Age, while the community of Eretria retreated from the coast to the more defensible site of the later acropolis, and occupation at Magoula 


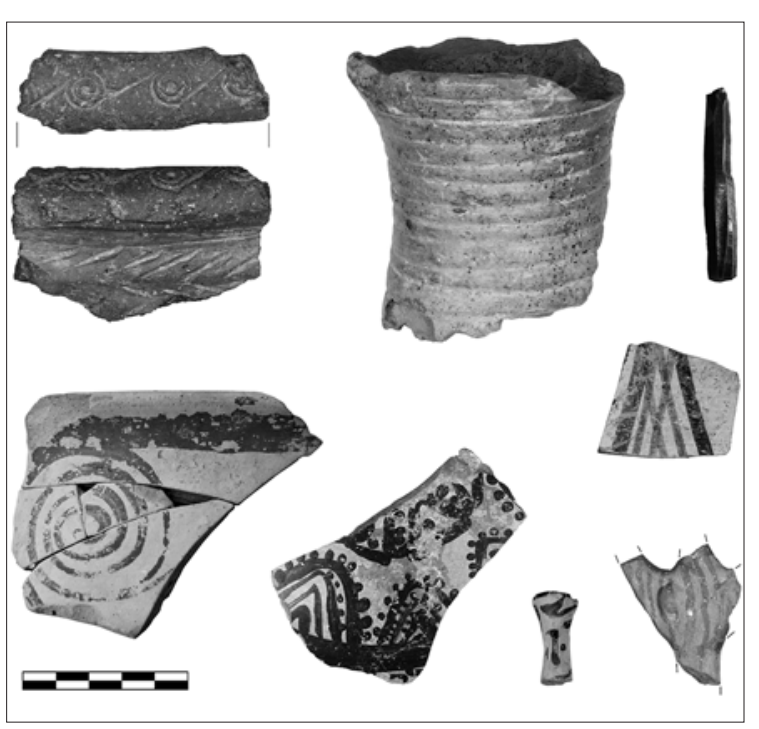

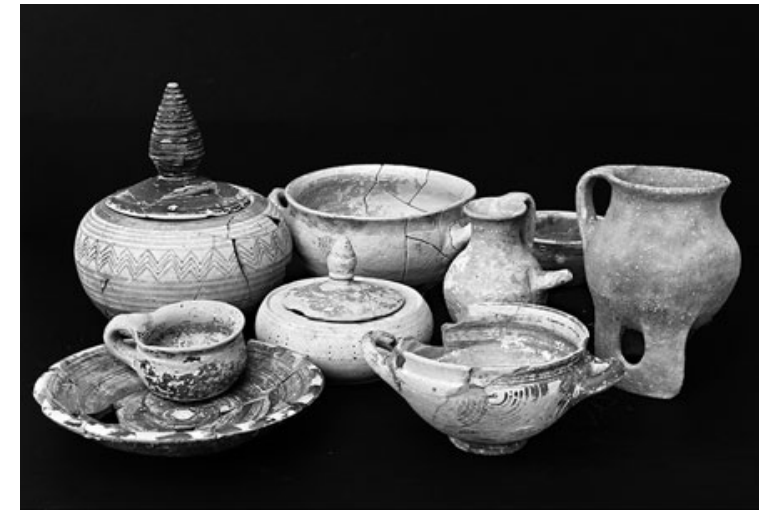

136. Paleoekklisies: pottery from the Middle Geometric grave (Kokkalas plot). (C) ESAG.

135. Paleoekklisies: Early to Late Bronze Age pottery and small finds. (C) ESAG.

nearly ceased. This pattern seems to follow a wider trend of nucleation manifested in the region during this period and paralleled in the rest of central Euboea and at Oropos (Cosmopoulos 1998; Krapf 2017).

Structures identified in 2006 belong to a rectangular double-room house with two building phases of the second half of the Middle Bronze Age. An inhumation of an adult was found in the eastern room, inside a simple pit without any offerings; in the western room a coarse-ware jar with a pierced base was found sunk into the floor and covered with fragments of a matt-painted vase (ID529; Theurillat and Fachard 2007; Krapf 2011; 2015).

The pottery recovered from Paleoekklisies hill spans the entire Late Bronze Age down to the Late Helladic IIIC. The pictorial-style sherds collected by the British survey stand out from the rest of the corpus, but no further fragments have been found subsequently. A possible Mycenaean layer was located in 2007 just south of the modern road, but has not been explored any further (Fachard and Theurillat 2008). On the opposite side of the road, a tomb containing a Late Helladic II alabastron was excavated by the Ephorate, together with the above-mentioned Early Bronze Age structures (Kalamara 2015: 157). The Mycenaean figurines, human and animal, found in the slope deposits are too few to provide sufficient evidence of early cult activity at the site. The finds, however, do indicate the presence of a sizeable settlement - no doubt the only major Mycenaean site located between Aliveri and Lefkandi (especially if one considers the rarity of comparable finds from Eretria, which was mainly occupied in the Early and Middle Bronze Age). This supports its identification with Late Bronze Age a-ma-ru-to and, in all likelihood, the site of the later Sanctuary of Amarynthos, which, given the antiquity of its name, should be sought at a location with substantial Mycenaean remains.

\section{The Early Iron Age}

Our knowledge of the transition to the Iron Age and the occupation of the early first millennium BC on the site is still fragmentary. Early Iron Age remains are absent from the summit of Paleoekklisies hill. However, discoveries made at the foot of the promontory show that the edge of the cove created by the Prehistoric bay was occupied between the Protogeometric and Geometric periods. The oldest remains are burials, including a Middle Geometric I child grave containing nine vessels (Fig. 136; ID448; Blandin 2008; Léderrey 2008). Part of a massive eighth-century BC wall, $80 \mathrm{~cm}$ wide, was excavated under the East Stoa. An Early Archaic building in antis (Ed. 3) is reminiscent of the monumental public 'halls' discovered throughout Greece (at Emporio, Eleusis, Kalapodi, to cite only three parallels). In plan, the building is at least $12.50 \mathrm{~m}$ long and $5.50 \mathrm{~m}$ wide; two antae made of orthostats were carefully laid out, forming the entrance to the building on the northeast (Fig. 137). Since its southern extension remains to be excavated, we do not know if its plan was apsidal or rectangular. A gravel roadway ran alongside the building, edged by a terrace wall serving as a limit. 


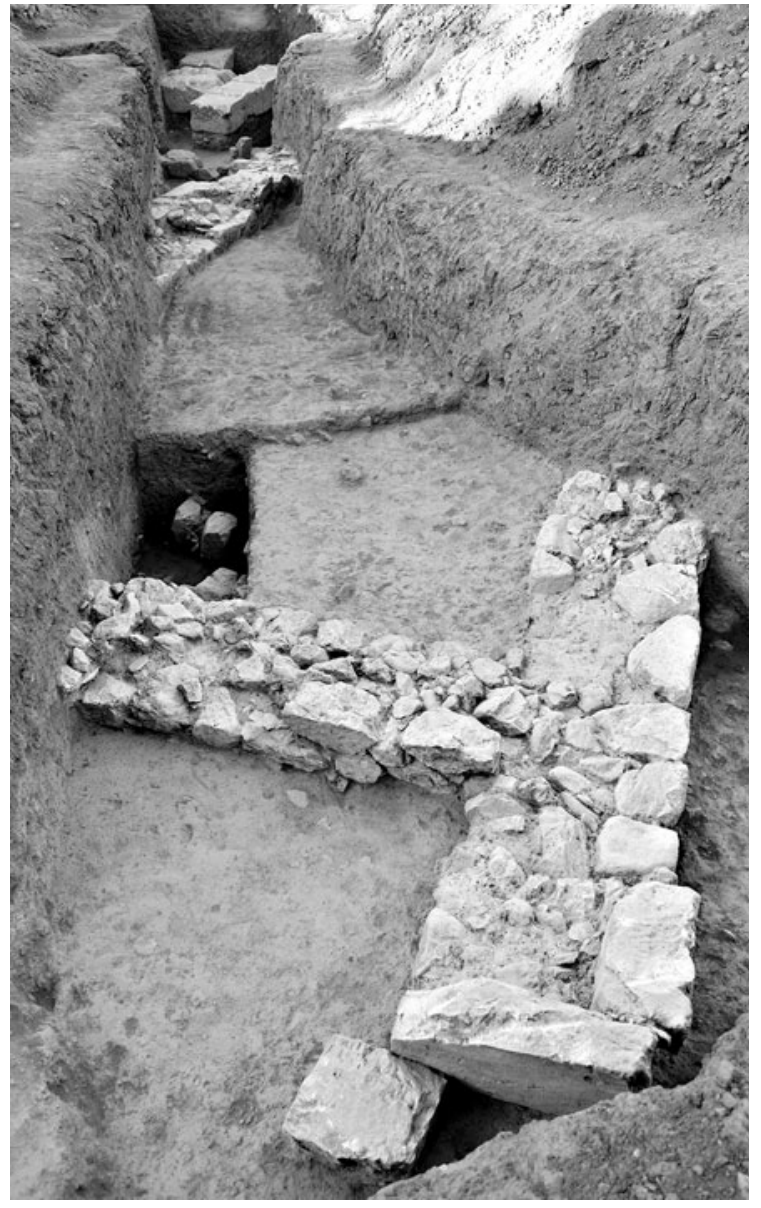

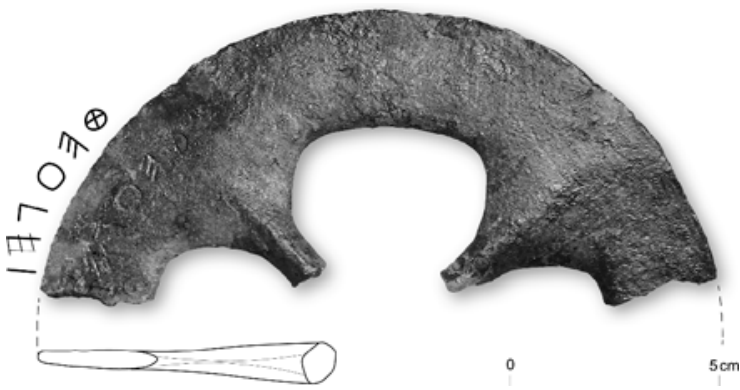

138. Paleoekklisies: inscribed miniature bronze wheel. (C) ESAG.

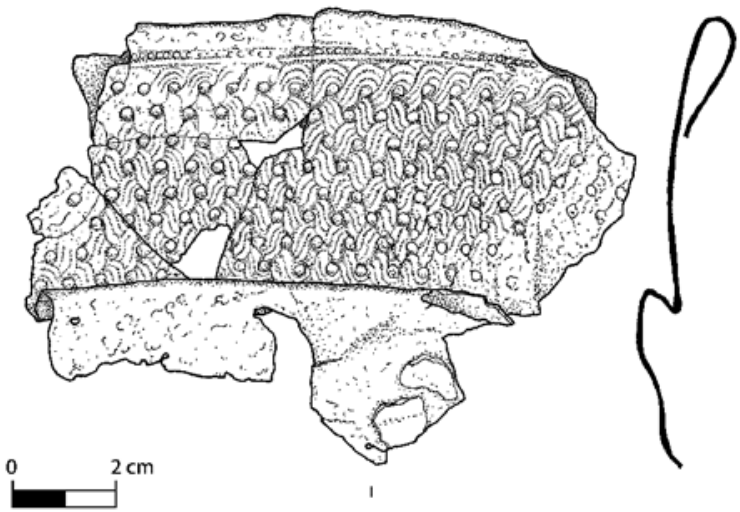

139. Paleoekklisies: fragments of miniature bronze shield. (C) ESAG.

A pit situated between the roadway and the building contained a fragment of a small bronze wheel, which bears the name $\Theta \varepsilon$ o $\gamma$ - inscribed from right to left (Fig. 138; Knoepfler et al. 2015: 146). Other votive offerings from the eighth and seventh centuries BC were also discovered out of context in later backfills: fragments of bronze shields (Fig. 139), a serpentine seal from the 'Lyre Player Group' (Knoepfler et al. 2016: 100, fig. 12) and several graffiti inscribed on pottery and terracotta. The excavation recovered very little material from the sixth century BC. Remains from this period are likewise rarely encountered at Eretria.

\section{The Classical and Hellenistic periods}

In the course of the fifth century BC, a tamped roadway (at least $3.50 \mathrm{~m}$ wide) was built over its Archaic predecessor, following the same orientation and delimited on one side by a new rubble wall. Traces of wheel-ruts are preserved on its surface. In the first half of the fourth century, a rectangular building (Ed. 2), opening onto the west, was built on the Classical roadway. Its plan, only preserved to the level of its foundations, measures $12 \mathrm{~m} \times 9 \mathrm{~m}$, with two bases meant to support semi-engaged pilasters separating the interior into two equal spaces. The plan is reminiscent of oikoi, buildings of various functions that are found in sanctuaries. The superstructure, as well as its associated floor level, were removed during the construction of the East Stoa.

The most impressive discovery to date is an elongated two-aisled stoa, $11.80 \mathrm{~m}$ in width and at least $50 \mathrm{~m}$ in length (southwest to northeast) (Figs 133, 134 and 140; ID2962, ID4225, ID5062, ID5446). It overlies the earlier roadways and has a similar orientation, thus maintaining the structured axis in place since the seventh century BC. The stoa faces west, suggesting that it bordered a large courtyard, maybe the aulè mentioned in the Eretrian law of the Artemisia (see above and IG XII 9, 189; Rhodes and Osborne 2003: 
73). The overall dimensions and plan of the building remain unknown, as only a portion has been excavated. The stoa did not have a rectangular plan, however; to the north, the plan draws an angle and continues at least $5 \mathrm{~m}$ toward the west (Fig. 133). Therefore, this extension points toward the existence of a projecting wing, unless it is part of an L- or П-shaped stoa.

The front colonnade rests on a foundation made of two courses of conglomerate blocks, set in headers and stretchers respectively (average size of blocks: $1.30 \mathrm{~m} \times 0.64 \mathrm{~m} \times 0.40 / 50 \mathrm{~m})$. Two blocks were fixed by a double-dovetail clamp, and a mortise with an iron dowels was used to fix a block of the euthynteria. The colonnade had a Doric entablature, attested by the discovery of a limestone frieze block $(2.60 \mathrm{~m} \times$ $0.56 \mathrm{~m} \times 0.49 \mathrm{~m}$ ) with a three-metope span (Fig. 140), as well as a fragment of the cornice. The stoa had a double-faced central colonnade (Fig. 133), with an intercolumniation of $5.20 \mathrm{~m}$, resting on foundation pillars made of two adjacent conglomerate blocks $(0.72 \mathrm{~m} \times 0.63 \mathrm{~m} \times 0.40 \mathrm{~m})$. The inner colonnade most certainly carried wooden beams. The plan is ordered according to a $5.20 \mathrm{~m}$ module (probably the equivalent of 16 Doric feet of $c a .0 .326 \mathrm{~m}$ ), which regulates the inner colonnade as well as the depth of the two aisles.

Except for the two fragments mentioned above, no elements of the limestone colonnades or the entablature of the stoa have survived. Some architectural elements might have been reused ( $c f$. a similar frieze block in the back wall of the Panagitsa church some $2 \mathrm{~km}$ from the site), but most of them were probably consumed in a Medieval lime kiln built on the facade of the stoa. Only the back wall, currently the most massive and complex element of the building, has

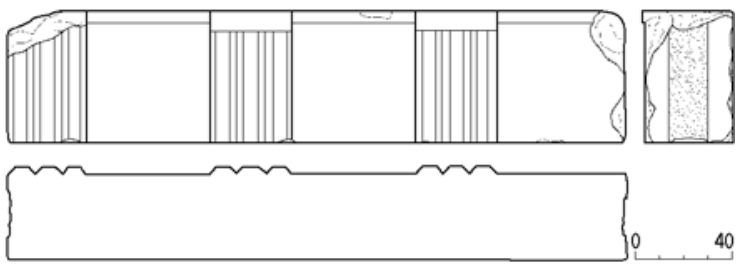

140. Paleoekklisies: frieze block from the Doric entablature of the East Stoa. (C) ESAG.

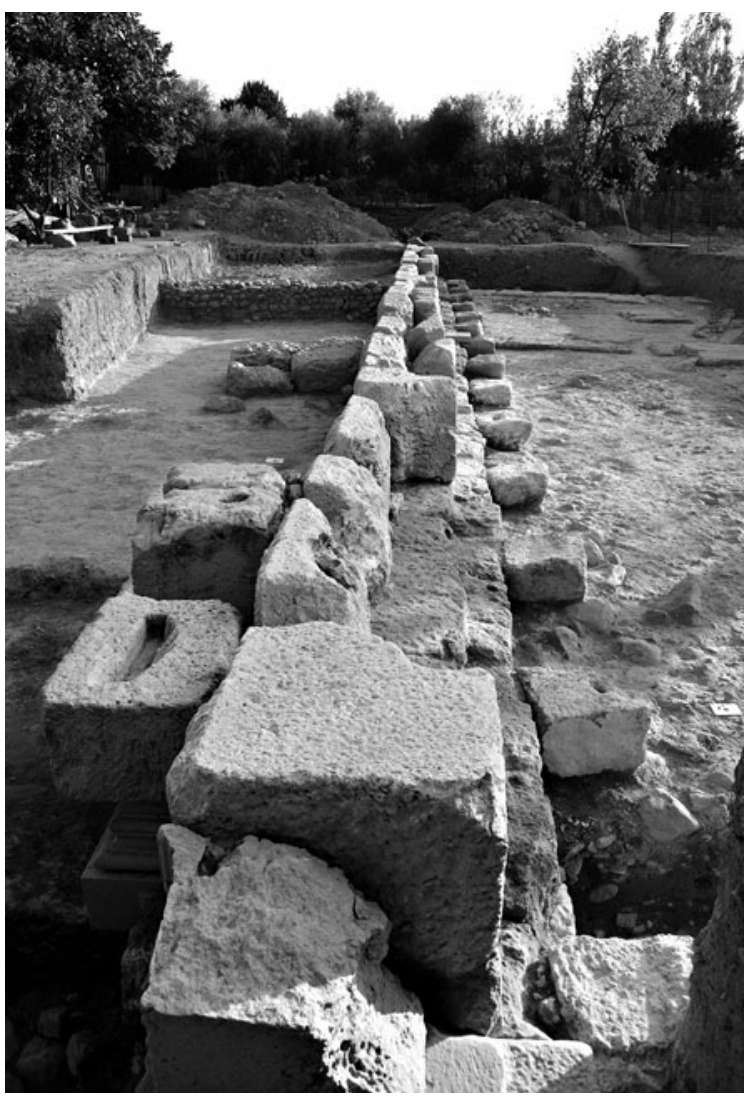

141. Paleoekklisies: back wall of the East Stoa. (C) ESAG. been left in place (Fig. 141). The wall is made of two rows of orthostats averaging half a ton. The orthostats rest on two courses of conglomerate blocks: one course set in stretchers and the other in headers. Prise marks are visible on the upper course. The width of the combined orthostates is $0.73 \mathrm{~m}$, preserved on a single course some $0.72 \mathrm{~m}$ high. The masonry is trapezoidal to polygonal isodomic, with regular use of rabbeting. The outer blocks are quarry faced, and some have a broached surface, while the blocks of the inner face have a dressed surface. An anathyrosis that runs along the bedding surfaces of the blocks suggests the existence of a levelling course. The back wall of the stoa, therefore, consisted of a mud-brick elevation on a dressed-stone socle. In all probability, the floor of the stoa was made of beaten earth. Regarding the chronology of the stoa, the excavation of the foundation trenches has provided a firm date in the second half of the fourth century BC, perhaps in its third quarter.

In a second phase (third century BC), a stone bench was added along the back wall of the stoa (Fig. 142). Coarse conglomerate foundation blocks $(0.50 \mathrm{~m} \times 0.50 \mathrm{~m})$ for the brackets have been found at an interval of some $1.70 \mathrm{~m}$. These blocks supported a limestone slab serving as a base for moulded brackets. Only one slab $(0.52 \mathrm{~m} \times 0.37 \mathrm{~m} \times 0.11 \mathrm{~m})$ has been found in situ; its bedding surface, carefully levelled with a claw, has two mortises with pour channels. Several foundation blocks of the back wall were cut in order to accommodate the slabs. 


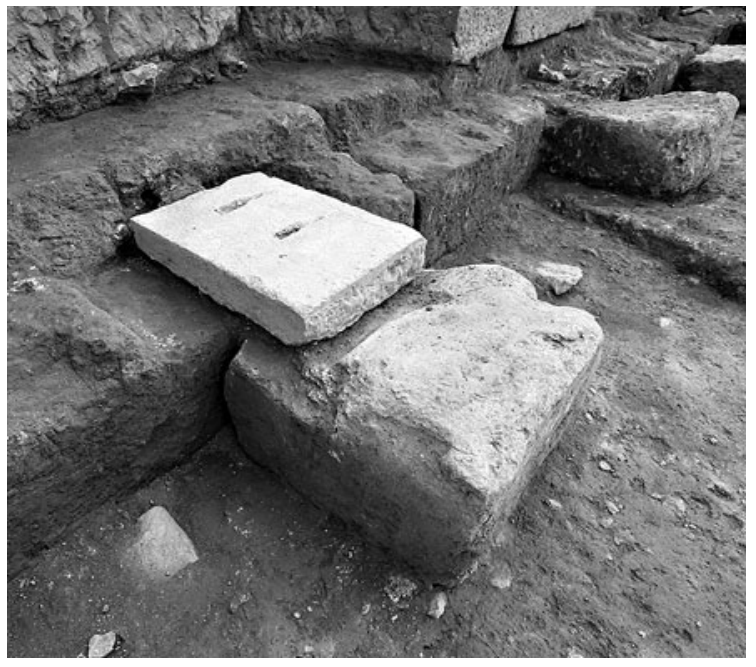

142. Paleoekklisies: base of the bench (St28) in the East Stoa. (C) ESAG.

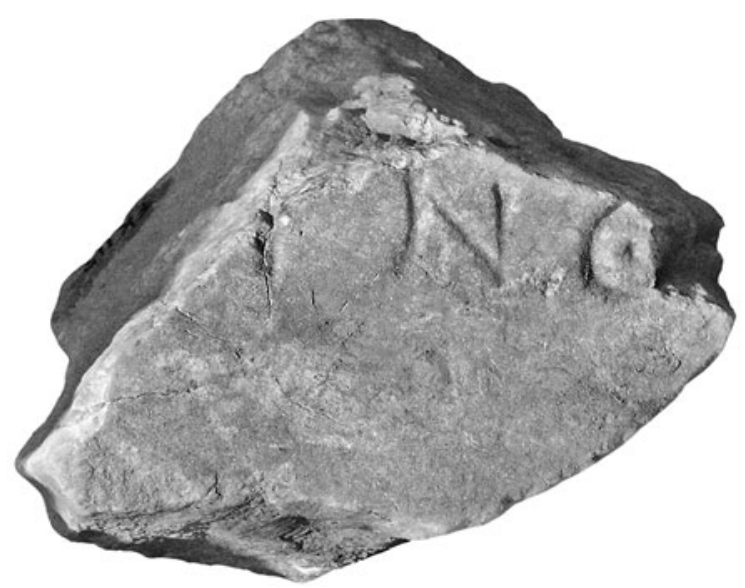

143. Paleoekklisies: fragment of an inscription showing letters which could be rendered as [Év A $\mu \alpha \rho] v \dot{v} \theta[\omega \imath]$. (C) ESAG.
In its last phase in the third century $\mathrm{BC}$ a monumental entrance was added to the northeastern section of the building. A large limestone threshold was added, forcing the builders to carve out a section of the bench. The surface of the stone shows very little trace of wear, suggesting perhaps that this entrance was not much used. The gate was flanked by two doorposts made of conglomerate blocks, moulded and stuccoed, resting directly on the surface of the threshold. The monumentality of the entrance was enhanced by the addition of a propylaion (3.50m deep), of which only the foundations are preserved.

A dozen bases for votive monuments were discovered in front of both the colonnade and the back wall. However, few fragments of sculptures and inscriptions were found. Despite the poor evidence, two inscribed fragments deserve special mention. The first one bears three letters - YN $\Theta-$

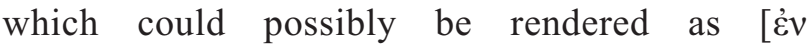
A $\mu \alpha \rho] v ́ v \theta[\omega t]$ (Fig. 143). The second fragment displays the first two letters of two lines; on the first line, the letters $\mathrm{O} \Delta$ [ must most probably refer to the

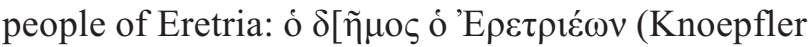
et al. 2014: 132, fig. 14).

A large esplanade was laid out to the east of the stoa, extending towards the foot of the Paleoekklisies hill. A building made of ashlar masonry was partially embedded into the hill and made accesible by means of a beaten-earth ramp. The plan of the building remains unknown, as only the northern and eastern walls have been excavated. The side (northern) wall is $10.90 \mathrm{~m}$ long and $0.56 \mathrm{~m}$ wide; an $8.50 \mathrm{~m}$-long stretch of the back (eastern) wall is currently visible, but it appears to continue towards the south (Figs 133, 134 and 144). The back wall was supported by engaged pillars acting as internal buttresses, constructed to resist the lateral pressure of the soil. In spite of the pillars, however, the rear wall fell apart, and its blocks were scattered inside the building. Based on the position of the collapsed blocks on the beaten-earth floor, the rear wall was at least $2.25 \mathrm{~m}$ high in five courses. All blocks are carved in a fine shelly sandstone. The northern wall is preserved in two courses, resting on an euthynteria whose blocks have lifting bosses. The masonry is isodomic ashlar. The inner faces of the top two courses have been very carefully dressed, while the outer face appears to have been partly unfinished (some blocks display drafted margins all round). An anathyrosis band was used on the lateral joints. The blocks have prise marks, but no traces of clamps or pins. The blocks display a very high quality of craftsmanship.

The plan and internal layout of the building remain poorly known, as does its date, which can only be generally fixed in the Late Hellenistic period. The walls of the building are the finest discovered so far at Amarynthos. The monument, facing the esplanade, might have been an analemma, an exedra or even a portico. Whatever its function, it held a prominent position at what appears to be the eastern entrance to the sanctuary. Future excavations should clarify the function and date of this monument. 


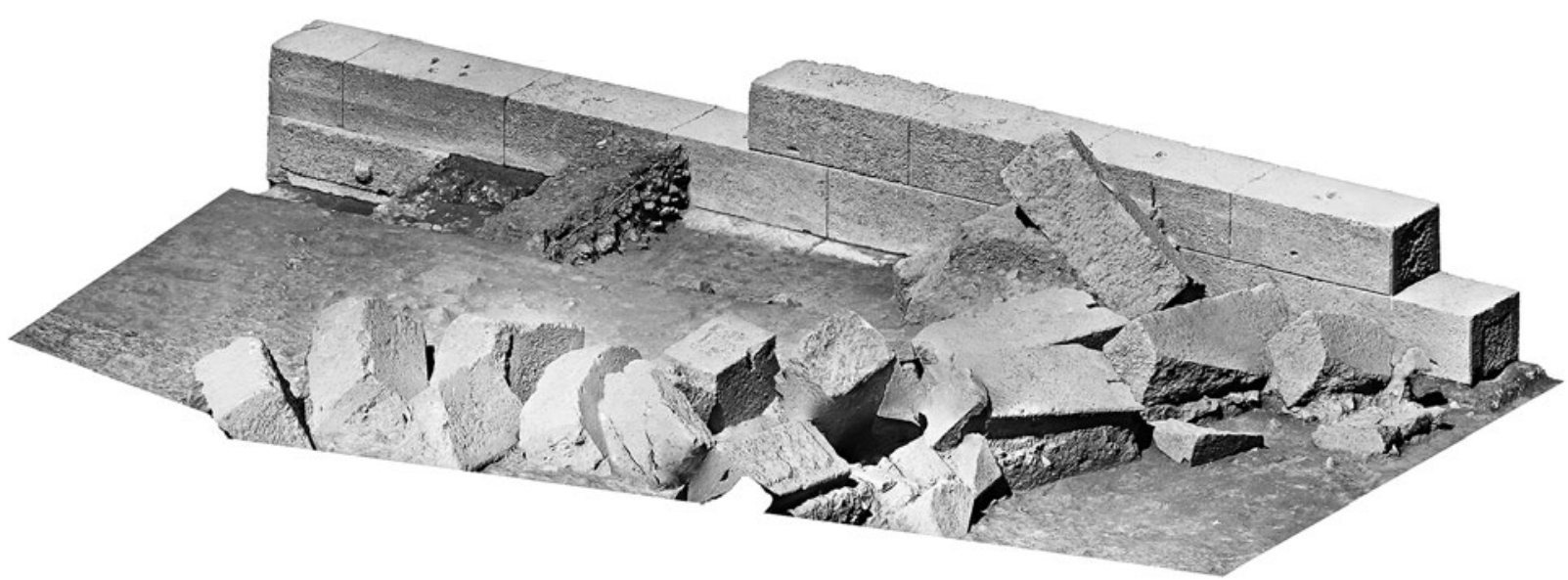

144. Paleoekklisies: northern wall and collapsed blocks of the Late Hellenistic building (Ed. 4). (C) ESAG.

\section{The Medieval period}

Traces of Medieval occupation have been found in the area of the East Stoa. Large quantities of pottery, mostly tableware dated from the $13^{\text {th }}$ to the $16^{\text {th }}$ century $\mathrm{AD}$, have been uncovered east of the building, which must still have been visible, as attested by a dry-stone enclosure wall built against it. Many of these sherds continue the Byzantine tradition, while others can be related to the ceramic production of Italy. Furthermore, a hearth and a pit with burnt animal bones were located above Building 4. Last, the presence of a large lime kiln built on the western wall of the stoa demonstrates that the marble and limestone blocks from the various ancient buildings were calcined. These features, dated to the transitional

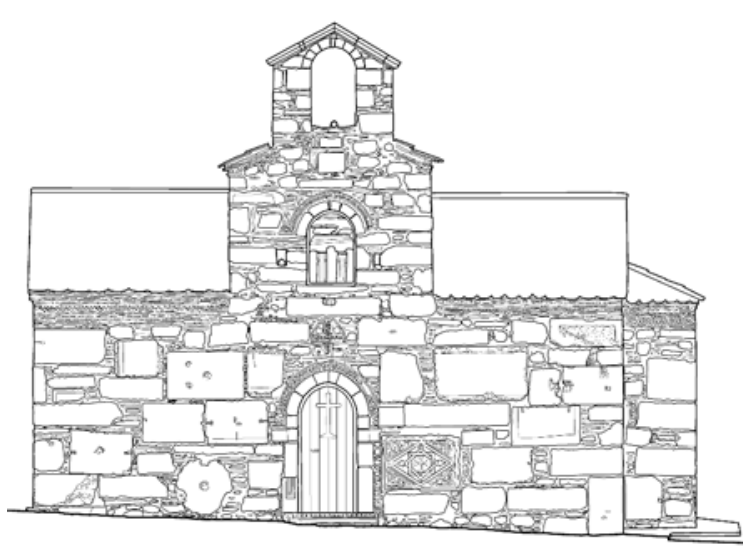

145. Panagitsa church, a short distance from Paleoekklisies.

(C) ESAG. phase between Venetian and Ottoman rule on the island, are contemporary with the two churches on top of Paleoekklisies hill (Orlandos 1951: 130; Koder 1973: 102-03, fig. 33). A Medieval fortified settlement must have been located here, before the creation of the Ano Vatheia village (Sathas 1882: 447; Koder 1973: 30-31, 102-03; Koder and Hild 1976: 132; Ackermann and Knoepfler 2009: 128-29; Kalamara 2017: 542-43). The current research programme includes the systematic recording of ancient blocks reused in buildings of the region, as in the two churches on Paleoekklisies hill and the Panagitsa church in the heart of the valley (Fig. 145).

\section{Conclusion}

The excavations conducted over the course of the last decade have revealed the existence of a monumental complex at the foot of Paleoekklisies hill in Amarynthos. This area is recorded on a French map of 1852 with the telling toponym 'Ta Marmara', no doubt due to the significant presence of ancient marbles there. Inscriptions - including $I G$ XII 9, 142 which mentions the Artemisian Triad (as do many other similar pedestals from this sanctuary) - were found in this sector. Although the accurate identification and function of the newly excavated buildings remain to be clarified, it is not too premature to stress that porticoes, oikoi and buildings in antis are most often built in sanctuaries. The ceramic evidence from the current excavations does not fit the pattern of a settlement. Moreover, no other site in the Eretrian territory currently displays the size, quality of workmanship and monumentality of the buildings found in Amarynthos. Last, although the route of the Sacred Road linking Eretria with the sanctuary is not precisely known, the most 
direct route between the East Gate of Eretria and the stoa of Amarynthos is $10.3 \mathrm{~km}$, a distance which almost perfectly matches the (amended) 60 stadia $(10.8 \mathrm{~km})$ given by Strabo. There is, in short, considerable and compelling evidence that the structures excavated during the last decade at the foot of Paleoekklisies hill represent the archaeological remains of the Sanctuary of Artemis Amarysia.

While we are convinced that this is the correct conclusion, we acknowledge that incontrovertible written evidence remains elusive. However, we are confident that future work at the site will eventually produce such evidence. Plans for future excavations are moving forward. Having acquired the private plots that resulted in the discovery of the East Stoa, ESAG was able to purchase and donate to the Greek government an additional plot of $4,000 \mathrm{~m}^{2}$ - thanks to the generosity of several benefactors (the Swiss government, the Sandoz Family Foundation and the Dreyfus-Bernheim Foundation). This plot includes the western extension of the stoa and the area which could correspond to the courtyard or aule of the Artemision. This purchase will allow us to carry out an open-area excavation of the remaining walls of the East Stoa, the Early Archaic building in antis, as well as the previously recorded Geometric layers.

This article closes a chapter and immediately opens a new one. Thanks to the support of the Swiss National Science Foundation, an ambitious programme of excavation and study has been planned and financed for the years 2017-2021. The project aims to excavate the Sanctuary of Artemis in order to study and understand the ritual practices carried out in this lieu de mémoire, where the collective identity of the Eretrian and Euboean people was shaped and reaffirmed over several centuries. Although the Artemision stood outside the city walls, it was at the core of the polis. The sanctuary's exploration will significantly broaden and challenge the current knowledge of the polis' history and institutions. In many ways, it might also change our understanding of the island of Euboea itself.

\section{Afterword}

Following the submission of this article, significant epigraphical and archaeological discoveries were made in the course of the 2017 excavation season. Stamped tiles bearing the name of Artemis, as well as three dedications on stone to Artemis, Apollo and Leto, now put the localization of the Sanctuary of Artemis Amarysia beyond doubt.

\section{Acknowledgments}

The authors would like to thank Sarah C. Murray for her help with this paper.

\section{Bibliography}

Ackermann, D. and Knoepfler, D. (2009) 'La région de Vathia/Amarynthos au miroir de ses premiers explorateurs, à propos d'une lettre inédite de P. Revelakis à L.-S.-F. Fauvel (1816)', Antike Kunst 52, 124-63

Aravantinos, V. (1988) 'Mycenaean place names from Thebes: the new evidence', in J.T. Killen, J.L. Melena and J.P. Olivier (eds), Studies in Mycenaean and Classical Greek Presented to J. Chadwick. Minos 20-22, 33-40

Blandin, B. (2008) 'Amarynthos au début de l'âge du fer à la lumière des fouilles récentes', Antike Kunst 51, 180-90

Boardman, J. (1957) 'Early Euboean pottery and history', BSA 52, 1-29

Cosmopoulos, M.B. (1998) 'Forschungen im Gebiet von Oropos: Die vorgeschichtliche Besiedlung', Prähistorische Zeitschrift 7, 52-68

Del Freo, M. (2009) 'The geographical names in the Linear B texts from Thebes', Pasiphae 3, 41-67

Fachard, S. (2004) 'Prospection géophysique à Amarynthos', Antike Kunst 47, 89-90

- (2005) 'Prospections à Amarynthos', Antike Kunst 48, 114

Fachard, S. and Theurillat, T. (2008) 'Amarynthos 2007', Antike Kunst 51, 154-59

Ghilardi, M., Fachard, S., Pavlopoulos, K., Psomiadis, D., Collana, C., Bicket, A., Crest, Y., Bonneau, A., Delanghe-Sabatier, D., Knodell, A.R. and Theurillat, T. (2012) 'Reconstructing mid-to-recent Holocene 
paleoenvironments in the vicinity of ancient Amarynthos (Euboea, Greece)', Geodinamica Acta 25, $38-51$

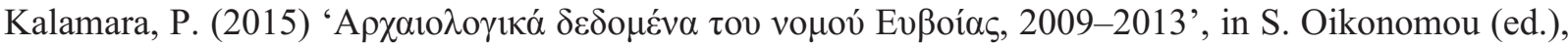

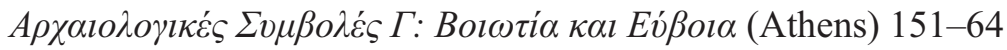

- (2017) 'The settlements of the Middle and Late Byzantine period in Euboea', in Z. Tankosić, F. Mavridis and M. Kosma (eds), An Island between two Worlds: The Archaeology of Euboea from Prehistory to Byzantine Times (Athens) 537-58

Knoepfler, D. (1972) 'Carystos et les Artémisia d'Amarynthos', Bulletin de correspondance hellénique 96, 283-301

- (1988) 'Sur les traces de l'Artémision d'Amarythos près d'Erétrie', Comptes rendus des séances de l'Académie des Inscriptions et Belles-Lettres, 382-421

- (2008) 'Amarynthos 2007: bilan et perspectives', Antike Kunst 51, 165-71

- (2010) La patrie de Narcisse: un héros antique enraciné dans le sol et dans l'histoire d'une cité grecque (Paris)

- (2015) 'The Euboian League: an “irregular” koinon?', in H. Beck and P. Funke (eds), Federalism in Greek Antiquity (Cambridge) 158-78

Knoepfler, D., Karapaschalidou, A., Fachard, S., Krapf, T., Baeriswyl, P. and Theurillat, T. (2014) 'Amarynthos 2013', Antike Kunst 57, 127-33

Knoepfler, D., Karapaschalidou, A., Krapf, T., Theurillat, T. and Ackermann, D. (2016) 'Amarynthos 2015', Antike Kunst 59, 95-102

Knoepfler, D., Kapaschalidou, A., Reber, K., Krapf, T., Theurillat, T. (2017) 'Amarynthos 2016', Antike Kunst 60, 135-45

Knoepfler, D., Karapaschalidou, A., Theurillat, T., Fachard, S., Baeriswyl, P. and Ackermann, D. (2015) 'Amarynthos 2014', Antike Kunst 58, 143-50

Koder, J. (1973) Negroponte: Untersuchungen zur Topographie und Siedlungsgeschichte der Insel Euboia während der Zeit der Venezianerherrschaft (Vienna)

Koder, J. and Hild, F. (1976) Tabula Imperii Byzantini I. Hellas und Thessalia (Vienna)

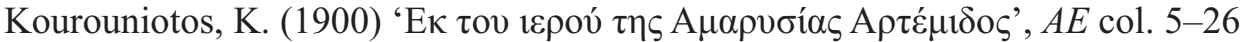

Krapf, T. (2011) 'Amarynthos in der Bronzezeit: der Wissensstand nach den Schweizer Grabungen 2006 und 2007', Antike Kunst 54, 144-59

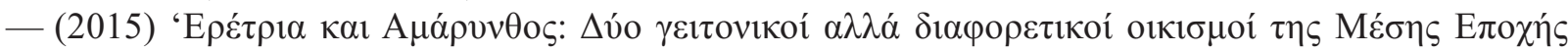

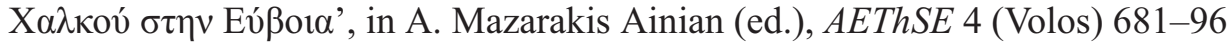

- (2017) 'Middle Helladic (central) Euboea and its cultural connections: the state of research', in Z. Tankosić, F. Mavridis and M. Kosma (eds), An Island Between Two Worlds: The Archaeology of Euboea from Prehistory to Byzantine Times (Athens) 145-58

Krentz, P. (2002) 'Fighting by the rules: the invention of the hoplite agôn', Hesperia 71, 23-39

Lasserre, F. (1971) Strabon, Géographie, Livre X (Paris)

Léderrey, C. (2008) 'Amarynthos 2007: ein subprotogeometrisches Kindergrab', Antike Kunst 51, 159-64

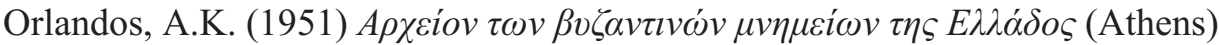

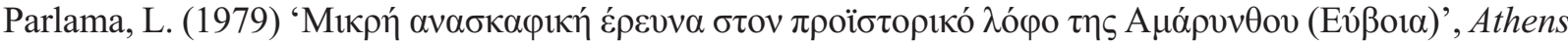
Annals of Archaeology 12, 3-14

Reber, K., Ackermann, G., Krapf, T., Bareswyll, P., Saggini, T. and Knoepfler, D. (2013) 'Amarynthos 2012: campagne de sondages', Antike Kunst 56, 100-07

Rhodes, P.J. and Osborne, R. (2003) Greek Historical Inscriptions, 404-323 BC (Oxford)

Richardson, R.B. (1895) 'A temple in Eretria', AJA 10, 326-37

Sackett, L.H., Hankey, V., Howell, R.J., Jacobsen T.W. and Popham, M.R. (1966) 'Prehistoric Euboea: contributions toward a survey', BSA 61, 33-112

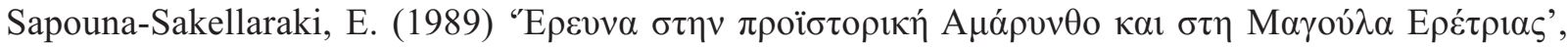
Archeion Euboikon Meleton 28, 91-104

- (1992) 'Un dépôt de temple et le sanctuaire d'Artémis Amarysia en Eubée', Kernos 5, 235-63 
Sathas, K.N. (1882) Documents inédits relatifs à l'histoire de la Grèce au Moyen Âge III (Paris) Schefold, K. and Auberson, P. (1972) Führer durch Eretria (Bern)

Themelis, P. (1969) 'Eretriaka', L'année épigraphique, 166-70

Theurillat, T. and Fachard, S. (2007) 'Campagne de fouilles à Amarynthos', Antike Kunst 50, 135-39

Wheeler, E.L. (1987) 'Ephorus and the prohibition of missiles', Transactions of the American Philological Association 117, 157-82 